\title{
Geobacillus stearothermophilus NUB3621R genetic transformation by electroporation
}

\section{Rūta Kananavičiūtè ${ }^{1 \star}$, \\ Indrẻ Kanišauskaitè ${ }^{1}$, \\ Vitalij Novickij ${ }^{2}$,}

\section{Donaldas Jonas Čitavičius ${ }^{1}$}

${ }^{1}$ Department of Microbiology and Biotechnology,

Faculty of Natural Sciences,

Vilnius University,

M. K. Čiurlionio St. 21/27,

LT-03101 Vilnius, Lithuania

${ }^{2}$ High Magnetic Field Institute,

Faculty of Electronics,

Vilnius Gediminas Technical University,

Naugarduko St. 41,

LT-13027 Vilnius, Lithuania
Background. Thermophilic bacteria of genus Geobacillus are valuable microorganisms that can be used in various biotechnological processes such as bioconversion and bioremediation. However, effective employment of geobacilli is impossible without a reliable and convenient methodology for their genetic engineering. In this study, we sought to elaborate an electrotransformation protocol for one of the most studied Geobacillus strain, G. stearothermophilus NUB3621R.

Materials and methods. To determine factors influencing transformation efficiency of the strain we have changed different conditions of electro-competent cells preparation (cell growth conditions, composition of eletrotransformation media) and parameters of electroporation itself (electric field strength).

Results. The best transformation efficiencies reaching $10^{3}$ of transformants per $\mu \mathrm{g}$ of DNA were achieved when the cells were grown to $\mathrm{OD}_{590}$ of 1.1-1.3 and suspended in hyperosmotic electrotransformation media composed of sorbitol, mannitol and glycerol. Moreover, the positive effect of $\mathrm{MgCl}_{2}$ has been demonstrated. The electric field strength of $20-22 \mathrm{kV} / \mathrm{cm}$ was most suitable for the transformation of NUB3621R strain.

Conclusions. The developed methodology allows transferring plasmid DNA to the cells of the G. stearothermophilus NUB3621R strain by electroporation. Although it is not sufficiently effective for some purposes (such like construction of DNA libraries and direct functional screening for desired enzymes), however, in this study determined conditions can serve as a starting point for further improvement of the electrotransformation protocol.

Key words: Geobacillus, electroporation, electrotransformation, genetic transfer technique

\section{INTRODUCTION}

Bacteria of the genus Geobacillus are gram-positive endospore-forming thermophiles that are

\footnotetext{
* Corresponding author. E-mail: ruta.kananaviciute@gf.vu.lt
}

a source of many biotechnologically relevant enzymes as well as producers of some valuable bio-chemicals. It is already proved that some genetically engineered strains of this genus can be very useful in ethanol production (Cripps et al., 2009), directed mutagenesis and expression of 
recombinant thermostable proteins (Kobayashi et al., 2015; Suzuki et al., 2013). Still, because of the scarcity of efficient genetic transformation systems, there are only few reports on successful employment of geobacilli.

G. stearothermophillus NUB3621R is one of the most studied Geobacillus strains (Blanchard et al., 2014). Wu and Welker (1989) have elaborated a protoplast transformation protocol that enables its genetic engineering. However, protoplast transformation is a cumbersome and time-consuming procedure. In our previous work we have demonstrated the possibility to transform the strain NUB3621R by electrotransformation for the first time (Kananavičiūte et al., 2014). Electrotransformation is a much more convenient and time-effective method, which can be applied to a wide variety of gram-positive and gramnegative bacteria, and once optimized, it gives high effectiveness $\left(10^{5}-10^{10}\right.$ of transformants per $\mu \mathrm{g}$ of plasmid DNA) (Aune, Aachmann, 2010). Electrotransformation comprises two main steps. The first electrocompetent cells are prepared, which can be stored at $-80{ }^{\circ} \mathrm{C}$ until use. Then the cells are mixed with the vector DNA, transferred to the electroporation cuvette (serves as an applicator) and subjected to a short high voltage pulse, which results in a high electric field generation inside the cuvette. Electric field causes reversible (or irreversible if electric field strength is too high) permeabilization of the cell membrane and allows entry of normally nonpermeant molecules into the cells (Young, Dean, 2015).

Electrotransformation has been already used to transform some Geobacillus strains, belonging to $G$. thermodenitrificans and $G$. thermoglucosidasius species (Narumi et al., 1992; Taylor et al., 2008). However, each bacterial species or strain has its own unique genetic and physiological features and, subsequently, requires different conditions for optimal electrotransformation.

Therefore, in the present work we investigate the influence of various electrotransformation conditions and parameters on the effectiveness of genetic transformation of the strain NUB3621R.

\section{MATERIALS AND METHODS}

\section{Bacterial strains and their routine growth conditions}

G. stearothermophilus NUB3621R (hsd(I) $\mathrm{R}^{-} \mathrm{M}^{-}$ rif $^{\mathrm{R}}$ ) strain was obtained from the Bacillus Genetic Stock Center. Routinely it was grown in the Nutrition Broth (NB; 1.0\% peptone, 0.5\% $\mathrm{NaCl}, 0.5 \%$ meat extract) or Nutrition Agar (NA; NB supplemented with $1.5 \%$ agar) medium at $55{ }^{\circ} \mathrm{C}$. When required, NB and NA media were supplemented with kanamycin to a final concentration of $12.5 \mu \mathrm{g} / \mathrm{ml}$. The E. coli DH5a (F-U80lacZDM15 $\Delta\left(\right.$ lacZYA $^{-}$argF) $\mathrm{U} 169$ recA1 endA1 hsdR17 (rK-, mK+) phoA supE44 $\chi$ - thi-1 gyrA96 relA1) strain was grown in the Lysogeny Broth (LB; $1.0 \%$ peptone, $0.5 \% \mathrm{NaCl}, 0.5 \%$ yeast extract) or Lysogeny Agar (LA; LB with 1.5\% agar) medium. When required, media were supplemented with ampicillin to a final concentration of $100 \mu \mathrm{g} / \mathrm{ml}$.

\section{Plasmids, their isolation and identification}

In this work we used two E. coli-Geobacillus spp. shuttle plasmids:pUCG18 (pMB1 replicon, Amp ${ }^{\mathrm{R}}$, pBST1 replicon, $\mathrm{Kan}^{\mathrm{R}}$; Taylor et al., 2008) and pUCK7 (pMB1 replicon, Amp ${ }^{\mathrm{R}}$, pGTD7 replicon, Kan ${ }^{\mathrm{R}}$; Kananavičiūtè et al., 2014). Plasmids were isolated from E. coli DH5a or G. stearothermophilus NUB3621R strain cells using a GeneJET Plasmid Miniprep Kit (Thermo Fisher Scientific) according to the manufacturer's protocol. Extracting the plasmid DNA from G. stearothermophilus NUB3621R, some modifications were introduced into the protocol. Briefly, the harvested NUB3621R cells were suspended in a resuspension solution supplemented with lysozyme (final concentration $2.5 \mathrm{mg} / \mathrm{ml}$ ) and incubated for $15 \mathrm{~min}$ at $37^{\circ} \mathrm{C}$. The isolated plasmids were identified by restriction analysis. The concentration of the plasmid DNA was evaluated by spectrophotometric and electrophoretic 
analysis using a MassRuler DNA Ladder Mix (Thermo Fisher Scientific).

\section{G. stearothermophilus NUB3621R electro- transformation}

Preparation of electro-competent cells

To prepare electro-competent cells, the G. stearothermophilus NUB3621R strain was grown in the ANB medium (NB medium supplemented with $2.30 \mathrm{mM} \mathrm{CaCl}_{2}, 1.10 \mathrm{mM} \mathrm{MgCl}_{2}$, $0.07 \mathrm{mM} \mathrm{KCl}, 0.91 \mu \mathrm{M} \mathrm{ZnSO}_{4}, 0.47 \mu \mathrm{M} \mathrm{MnSO}_{4}$ ) with aeration at $55^{\circ} \mathrm{C} .1 \mathrm{ml}$ of the overnight culture was transferred into $100 \mathrm{ml}$ of fresh medium and grown to an appropriate value of $\mathrm{OD}_{590}(0.5,0.7,0.8,1.1,1.2,1.4)$. The cells were cooled on ice for $10 \mathrm{~min}$ and centrifuged at $4{ }^{\circ} \mathrm{C}$ $8000 \mathrm{~g}$ for $10 \mathrm{~min}$. The pellet was washed four times with ice-cold electro-transformation medium (ETM) and suspended in approximately $1 \mathrm{ml}$ of the same medium to reach $\mathrm{OD}_{590}$ of 100 . Four different ETM were used: G (10\% glycerol), SMG (10\% glycerol, $0.4 \mathrm{M}$ sorbitol, $0.4 \mathrm{M}$ mannitol), SMGM (SMG medium supplemented with $1 \mathrm{mM} \mathrm{MgCl}_{2}$ ) and TG (10\% glycerol, $0.5 \mathrm{M}$ trehalose). The suspension was divided into $50 \mu \mathrm{l}$ aliquots and used for transformation immediately or stored at $-70^{\circ} \mathrm{C}$ until use.

\section{Electroporation}

The prepared electro-competent cells were mixed with $100 \mathrm{ng}$ of plasmid DNA (pUCG18 or pUCK7 isolated from DH5a or NUB3621R strains). Then, cells were loaded into an ice-cold 1-mm gap electroporation cuvette and subjected to a single pulse generated by an Eppendorf Multiporator (exponentially-decaying pulse, $5 \mathrm{~ms}$ time constant, $600 \Omega$ resistance, $10 \mu \mathrm{F} \mathrm{ca-}$ pacitor). Separate experimental instances when the voltage was set to $1.6,1.8,2.0,2.2$ or $2.4 \mathrm{kV}$ were performed. After electroporation, the cells were immediately transferred into $1.5 \mathrm{ml}$ of medium identical to the growth medium and incubated at $52^{\circ} \mathrm{C}$ for $2 \mathrm{~h}$ with shaking $(180 \mathrm{rpm})$ to allow expression of the antibiotic resistance gene. Finally, transformants were selected by spreading the cell suspension on the ANB agar medium with kanamycin $(12.5 \mu \mathrm{g} / \mathrm{ml})$. The plates were incubated overnight at $55^{\circ} \mathrm{C}$.

\section{Cells viability determination}

The evaluation of cell viability was performed by counting colony-forming units ( $\mathrm{CFU})$. The prepared electrocompetent cells were placed into an ice-cold cuvette and electroporated using 16 , $18,20,22$, or $24 \mathrm{kV} / \mathrm{cm}$ electric field. After that the cells were diluted with the ANB medium, spread on the agar medium and incubated at $55^{\circ} \mathrm{C}$. The $\mathrm{CFU}$ was counted after $12 \mathrm{~h}$ of incubation. The colonies after electroporation were compared to the non-treated samples (control). The viability was determined as percentage of $\mathrm{CFU}$ in respect to the control.

\section{RESULTS AND DISCUSSION}

\section{Growth phase}

The first step in our work was to determine the $\mathrm{OD}_{590}$ value of the growing NUB3621R culture, at which harvested cells were most electrocompetent. Electro-competent cells of various other bacteria are prepared from exponentially growing cells. However, harvesting cells at different points of the exponential phase results in different transformation efficiency and the optimal harvesting point is species or even strain dependent. In the case of Bacillus subtilis (relative to Geobacillus spp.), some of strains are most effectively transformed when they reach an early log phase, while mid log or late log phases are most suitable for other strains. Some of the strains are transformable only in a very narrow range of culture $\mathrm{OD}_{590}$ (Lu et al., 2012).

To evaluate the influence of a growth stage on the transformation efficiency of G. steraothermophilus NUB3621R, the cells were grown in the ANB medium (NB medium supplemented with salts listed in section 2.3.1) to different values of $\mathrm{OD}_{590^{\circ}}$. The $\mathrm{ANB}$ medium was chosen because analogous experiments using the $\mathrm{NB}$ medium (used for routine growth of strain NUB3621R) resulted in no transformants. This implies that salts present in the ANB medium alter cell physiology and at the same time positively influences transformability of the cells.

When the growing culture reached an appropriate $\mathrm{OD}_{590}$ value, cells were collected, suspended in SMG medium and treated by a $2 \mathrm{kV}$ 
pulse. The results (Fig. 1) indicate that transformants can be obtained from culture grown to $\mathrm{OD}_{590}$ from 0.7 to 1.4. However, the highest transformation efficacy is reached harvesting cells at $\mathrm{OD}_{590}$ of 1.3 .

\section{Electric field strength}

Electric field strength is one of the most important electroporation parameters influencing transformation efficiency. Higher electric field strength correlates with higher membrane permeability and subsequently higher transformation efficacy, but at the same time it negatively affects cell viability (Trevors et al., 1992). Thus, optimal electric field intensity for electrotransformation is when the cells are maximally permeabilized but cell viability is still sufficient to obtain high number of transformants.

To determine this value, we used electrocompetent cells prepared from the cells grown to $\mathrm{OD}_{590}$ of 1.3 and suspended in the SMG medium. The cells were mixed with the plasmid DNA and exposed to electric field strengths ranging from 16 to $24 \mathrm{kV} / \mathrm{cm}$. After electric shock, the transformation efficiency and the cell viability were evaluated (Fig. 2). About $90 \%$ of the cells remain viable after 16 and $18 \mathrm{kV} / \mathrm{cm}$ pulse. The further increase of the voltage results in a remarkable viability drop. In contrary, transformation efficiency positively correlates with higher electric field strength and reaches a peak at $20-22 \mathrm{kV} / \mathrm{cm}$. The pulse of $24 \mathrm{kV} / \mathrm{cm}$ is already too lethal to the cells resulting in a high inactivation of the colony.

It should also be mentioned that the results of identically performed experiments vary greatly and therefore high dispersion of the obtained data is observed. We suppose that one of the factors influencing variance of results is the pulse type generated by the electroporator we used in our study. The duration of the exponentially-decaying pulses depends on the time constant, which corresponds to the time necessary to discharge the capacitor and which depends on the capacitor capacitance and the resistance of the sample (Young, Dean, 2015). The variance of the amplitude of the applied electrical pulse during independent, but identical experimental instances did not exceed $\pm 2 \%$ of the set amplitude, however, the duration varied in the $\pm 15 \%$ range $(3.55 \pm 0.65 \mathrm{~ms})$. As a result, the variation in the transformation efficiency in several instances was higher than expected. Nevertheless, clear tendencies both

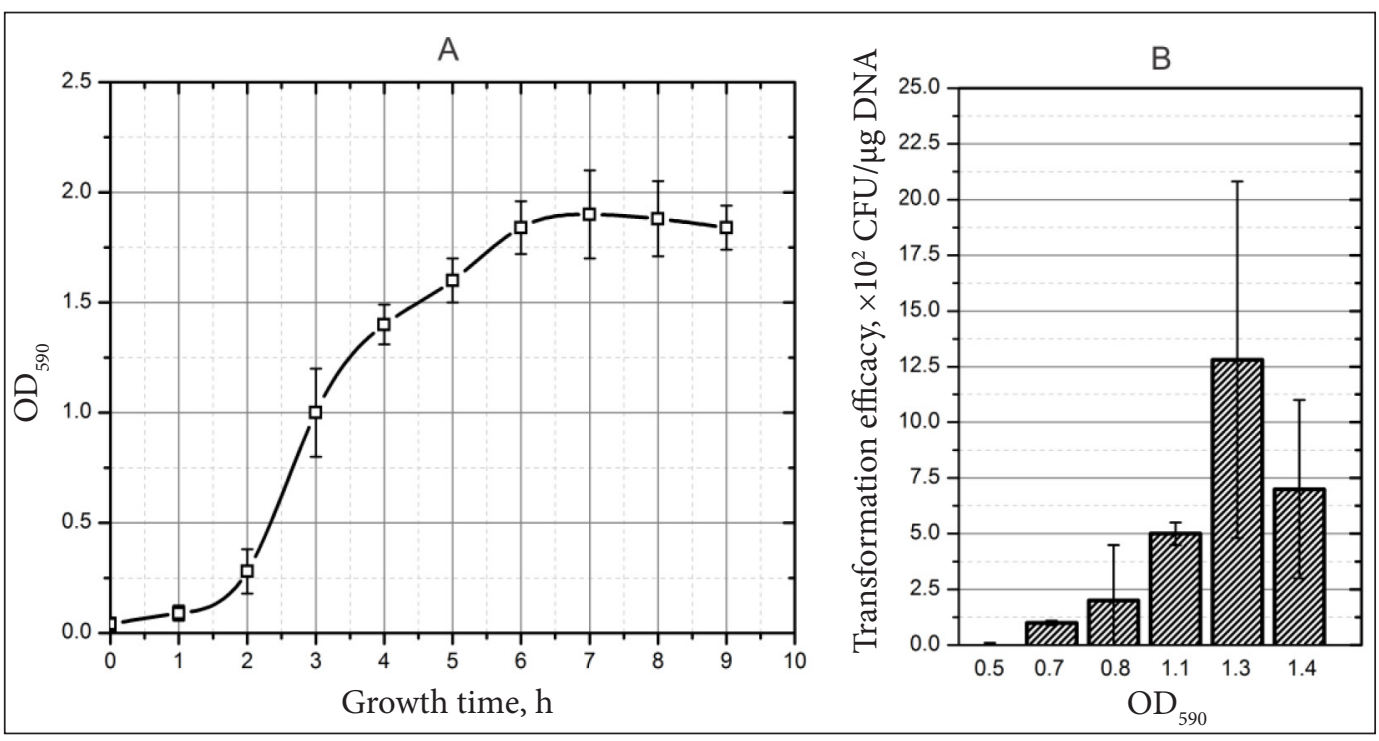

Fig. 1. The growth curve of G. stearothermophilus NUB3621R in ANB medium (A) and the transformation efficiency of NUB3621R cells grown until different growth phases in ANB medium 


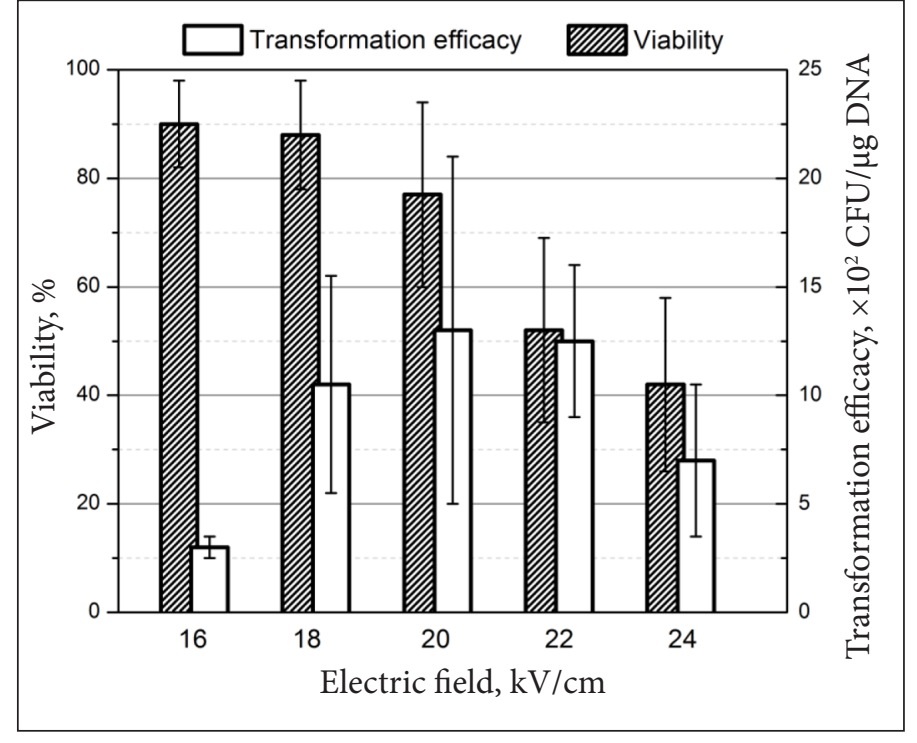

Fig. 2. The effect of applied electric field on cell viability and transformation efficacy in the kinetics of the inactivation of the colony and the transformation of G. stearothermophilus dynamics were acquired. A statistically significant $(\rho>0.95)$ decrease in viability was observed after $22-24 \mathrm{kV} / \mathrm{cm}$ electroporation compared to the $16-18 \mathrm{kV} / \mathrm{cm}$ experimental instances. The $22 \mathrm{kV} / \mathrm{cm}$ electroporation protocol positively affects the number of electrotransformated cells compared to the $16 \mathrm{kV} / \mathrm{cm}$ case $(\rho>0.95)$.

\section{Electroporation medium}

The electro-transformation medium also influences the transformation efficiency (its constituents may alter resistance of the sample and affect cell viability and/or mobility of DNA). In our study we analyzed four different ETM. Cells of the NUB3621R strain were grown to $\mathrm{OD}_{590}$ of 1.15, suspended in an appropriate ETM and treated by a $22 \mathrm{kV} / \mathrm{cm}$ pulse. The results are shown in the Table. The medium composed of $10 \%$ of glycerol (G medium) is used in the conventional electro-transformation protocols of E. coli and some other bacteria; however, this ETM is not suitable for G. stearotehrmophilus NUB3621R

Supplementation of the ETM with compatible solutes, such as sorbitol, mannitol or trehalose, enhances cell viability after electrical pulsing procedures, and subsequently may increase transformation efficiency (Xue et al., 1999;
Cao et al., 2011). The positive effect of these substances was also shown in our study; SMG and TG media yielded in $10^{2}$ transformants $/ \mu \mathrm{g}$ DNA. Additional supplementation of the SMG medium with $1 \mathrm{mM} \mathrm{MgCl}_{2}$ raised the efficiency by almost ninefold to $4.7 \times 10^{3}$. Thus SMGM media was proved to be most suitable for the transformation of strain NUB3621R.

Table. The effect of different ETM on transformation efficiency

\begin{tabular}{ccc}
\hline ETM & Composition & Efficacy \\
\hline G & $10 \%$ glycerol & 0.0 \\
\hline & $10 \%$ glycerol, & \\
SMG & $0.4 \mathrm{M}$ sorbitol, & $(5.2 \pm 2.5) \times 10^{2}$ \\
& $0.4 \mathrm{M}$ mannitol & \\
& $10 \%$ glycerol, \\
& $0.4 \mathrm{M}$ sorbitol, & $(4.7 \pm 4.3) \times 10^{3}$ \\
SMGM & $0.4 \mathrm{M}$ mannitol, \\
& $1 \mathrm{mM} \mathrm{MgCl} 2$ & \\
& $10 \%$ glycerol, & $(2.8 \pm 2.6) \times 10^{2}$ \\
\hline \multirow{3}{*}{ TG } & $0.5 \mathrm{M}$ trehalose $^{3}$
\end{tabular}

\section{Different plasmids isolated from different strains}

Various features of plasmids such as their sequence, size, replication type and their DNA modifications may have an effect on transformation efficiency. In our study we used two E. coli-Geobacillus shuttle plasmids that are 
similar in size, have same selection markers but replicates in geobacilli by different modes; plasmid pUCG18 employs theta type replication, plasmid pUCK7 replicates via a rolling circle mechanism. These plasmids were extracted either from E. coli DH5a or G. setarothermophilus NUB3621R strains. Electrocompetent NUB3621R cells grown to $\mathrm{OD}_{590}$ of 1.3 , suspended in SMG and treated by $20 \mathrm{kV} / \mathrm{cm}$ pulse were transformed with these plasmids.

The obtained results (Fig. 3) show that both plasmids are transferred to NUB3621R cells at similar efficiencies. Nevertheless, the isolation source of the plasmids influences noticeably the transformation efficiency. The plasmids pUCG18 and pUCK7 isolated from E. coli transform the NUB3621R strain about threefold less effectively than the plasmids isolated from the same strain (NUB3621R). This fact would not be surprising because it is well known that different species or even strains may have different restriction-modification (R-M) systems. R-M systems are responsible for modification of their host DNA, and for degradation of xenogeneic DNA, which is not modified or modified in different way. However, the G. steraotehrmophillus NUB3621R strain was considered as lacking in a functional restriction-modification system (Blanchard et al., 2014; Wu, Welker, 1989). Still, our results imply that NUB3621R is able to distinguish its own DNA from the foreign one and this leads to the lower transformation efficiency using the plasmid DNA extracted from other bacterial strains.

\section{CONCLUSIONS}

In this study we have determined the conditions that allow transforming G. stearothermophilus NUB3621R by electroporation. The best results were achieved by growing the cells in ANB to $\mathrm{OD}_{590}$ of 1.1-1.3, suspending them in ETM containing high concentration of compatible solutes (sorbitol and mannitol) and applying $20-22 \mathrm{kV} / \mathrm{cm}$. Applying these conditions, we obtained $10^{3}$ of transformants per $\mu \mathrm{g}$ of plasmid DNA on the average. High variations in the results were observed even though the experiments were performed under identical conditions. Presumably these variations are caused by the pulse type generated by the used electroporator. In our further studies we hope to solve this problem by using an electroporator generating square wave pulses for precise delivery of the pulse energy to the cells.

Received 6 September 2015 Accepted 28 October 2015

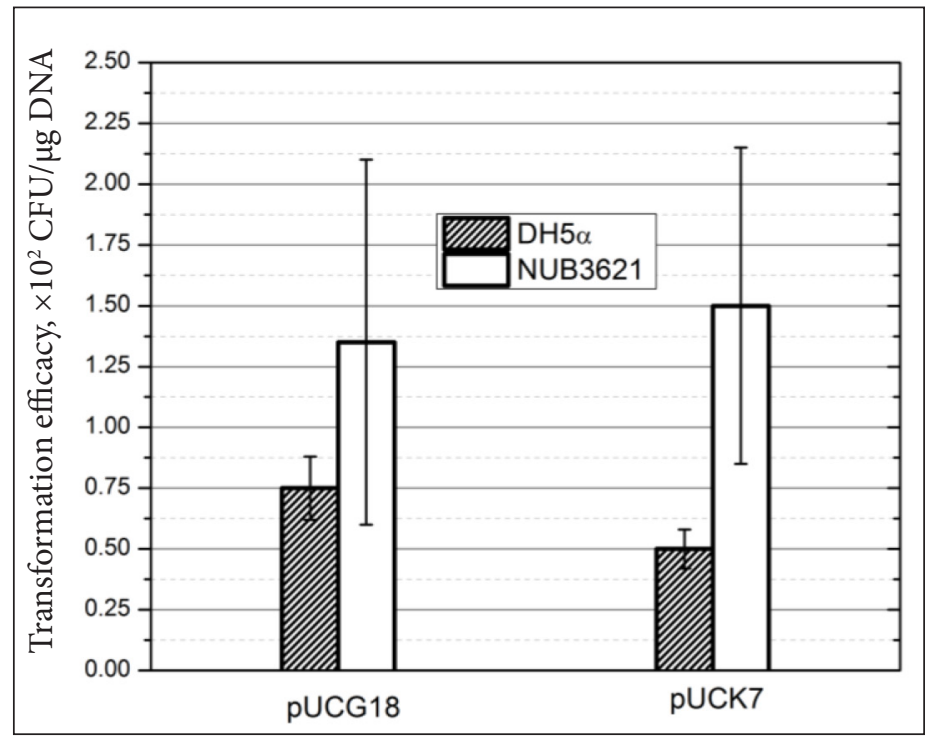

Fig. 3. The influence of different plasmids and their isolation source on transformation efficiency. Cells of strain NUB3621R were transformed with plasmids pUCG18 and pUCK7 isolated from E. coli DH5 $\alpha$ or the same strain (NUB3621R) 


\section{References}

1. Blanchard K, Robic S, Matsumura I. Transformable facultative thermophile Geobacillus stearothermophilus NUB3621 as a host strain for metabolic engineering. Appl Microbiol Biotechnol. 2014; 98(15): 6715-23.

2. Aune TE, Aachmann FL. Methodologies to increase the transformation efficiencies and the range of bacteria that can be transformed. Appl Microbiol Biotechnol. 2010; 85(5): 130113.

3. Cao G, Zhang X, Zhong L, Lu Z. A modified electro-transformation method for Bacillus subtilis and its application in the production of antimicrobial lipopeptides. Biotechnol Lett. 2011; 33(5): 1047-51.

4. Cripps RE, Eley K, Leak DJ, Rudd B, Taylor M, Todd M, Boakes S, Martin S, Atkinson T. Metabolic engineering of Geobacillus thermoglucosidasius for high yield ethanol production. Metab Eng. 2009; 11: 398-408.

5. Kananavičiūtė R, Butaite E, Čitavičius D. Characterization of two novel plasmids from Geobacillus sp. 610 and 1121 strains. Plasmid. 2014; 71: 23-31.

6. Kobayashi J, Furukawa M, Ohshiro T, Suzuki H. Thermoadaptation-directed evolution of chloramphenicol acetyltransferase in an error-prone thermophile using improved procedures. Appl Microbiol Biotechnol. 2015; 99(13): 5563-72.

7. Lu YP, Zhang C, Lv FX, Bie XM, Lu ZX. Study on the electro-transformation conditions of improving transformation efficiency for Bacillus subtilis. Lett Appl Microbiol. 2012; 55(1): 9-14.

8. Narumi I, Sawakami K, Nakamoto S, Nakayama N, Kimura T, Yanagisawa T, Kihara $\mathrm{H}$. A newly isolated Bacillus stearothermophilus K1041 and its transformation by electroporation. Biotechnol Tech. 1992; 6: 83-6.

9. Suzuki H, Yoshida K, Ohshima T. Polysaccharide-degrading thermophiles generated by heterologous gene expression in Geobacillus kaustophilus HTA426. Appl Environ Microbiol. 2013; 79(17): 5151-8.

10. Taylor MP, Esteban CD, Leak DJ. Development of a versatile shuttle vector for gene expression in Geobacillus spp. Plasmid. 2008; 60: 45-52.

11. Trevors JT, Chassy BM, Dowe WJ, Blaschek HP. Electroporation of bacteria by plasmid DNA. In: Chang DC, Chassy BM, Saunders JA, Sowers AE, editors. Guide to electroporation and electrofusion. Academic Press; 1992. p. 26590.

12. Young JL, Dean DA. Electroporation-mediated gene delivery. Adv Genet. 2015; 89: 49-88.

13. Xue GP, Johnson JS, Dalrymple BP. High osmolarity improves the electro-transformation efficiency of the gram-positive bacteria Bacillus subtilis and Bacillus licheniformis. J Microbiol Methods. 1999; 34: 183-91.

14. Wu LJ, Welker NE. Protoplast transformation of Bacillus stearothermophilus NUB36 by plasmid DNA. J Gen Microbiol. 1989; 135(5): 1315-24. 
Rūta Kananavičiūtė, Indrẻ Kanišauskaitė, Vitalij Novickij, Donaldas Jonas Čitavičius

\section{Geobacillus stearothermophilus}

NUB3621R KAMIENO GENETINE

TRANSFORMACIJA ELEKTROPORACIJOS METODU

\section{Santrauka}

Geobacillus genčiai yra priskiriamos termofilinès bakterijos, kurioms biotechnologijos srityje skiriamas ypatingas dèmesys. Geobacilos gali būti pritaikomos įvairiuose biokonversijos ir bioremediacijos procesuose, tačiau, siekiant efektyviai išnaudoti šiuos vertingus mikroorganizmus, būtina turèti patikimą ir patogią genetinès transformacijos metodologiją. Šiame darbe mes siekėme sukurti elektrotransformacijos protokolą, tinkamą vienam iš geriausiai ištirtų Geobacillus stearothermophilus kamienų - NUB3621R.

Tirdami veiksnius, turinčius įtakos elektrotransformacijos efektyvumui, mes keitème ịvairias elek- trokompetentinių ląstelių paruošimo sąlygas (ląstelių auginimo sąlygas, elektrotransformacijos terpès sudètị) ir elektroporaciją (elektrinio lauko stiprị).

Geriausi rezultatai $10^{3}$ transformatu mikrogramui plazmidinès DNR buvo gauti ląsteles auginant iki 1,1-1,3 $\mathrm{OT}_{590}$ vertès ir suspenduojant jas hiperosmotiniame buferyje, kurị sudaro glicerolis, sorbitolis ir manitolis. Be to, atskleistas teigiamas $\mathrm{MgCl}_{2}$ poveikis elektrotransformacijai. $20-22 \mathrm{kV} / \mathrm{cm}$ elektrinio lauko stipris buvo tinkamiausias NUB3621R kamieno transformacijai.

Aprašytas metodas leidžia perkelti plazmidinę DNR i G. stearothermophilus NUB3621R kamieno ląsteles. Nors gautas efektyvumas nèra pakankamas siekiant kai kurių tikslų (pavyzdžiui, DNR bibliotekų konstravimo), tačiau darbe nustatytos sąlygos gali būti atspirties tašku toliau tobulinant elektrotransformacijos metodą.

Raktažodžiai: Geobacillus, elektroporacija, elektrotransformacija, genetinès transformacijos metodologija 